\title{
Amyloid- $\beta$ peptide absence in short term effects on kinase activity of energy metabolism in mice hippocampus and cerebral cortex
}

\author{
FRANCINE R. IANISKI ${ }^{1}$, VIRGINIA C. RECH ${ }^{\mathbf{1}}$, VIVIAN S.K. NISHIHIRA ${ }^{\mathbf{1}}$, CATIANE B. ALVES ${ }^{\mathbf{1}}$, \\ MATHEUS D. BALDISSERA ${ }^{2}$, ETHEL A. WILHELM ${ }^{3}$ and CRISTIANE LUCHESE ${ }^{3}$
}

\author{
${ }^{1}$ Programa de Pós-Graduação em Nanociências, Centro de Ciências Tecnológicas, Centro Universitário \\ Franciscano, Rua dos Andradas, 1614, Conjunto I, 97010-032 Santa Maria, RS, Brasil \\ ${ }^{2}$ Departamento de Microbiologia e Parasitologia, Universidade Federal de Santa Maria, Av. Roraima, \\ 1000, Cidade Universitária, Bairro Camobi, 97105-900 Santa Maria, RS, Brasil \\ ${ }^{3}$ Centro de Ciências Químicas, Farmacêuticas e de Alimentos, Universidade Federal de \\ Pelotas, Campus Universitário, s/n, 96160-000 Capão do Leão, RS, Brasil
}

Manuscript received on October 20, 2015; accepted for publication on January 14, 2016

\begin{abstract}
Considering that Alzheimer's disease is a prevalent neurodegenerative disease worldwide, we investigated the activities of three key kinases: creatine kinase, pyruvate kinase and adenylate kinase in the hippocampus and cerebral cortex in Alzheimer's disease model. Male adult Swiss mice received amyloid- $\beta$ or saline. One day after, mice were treated with blank nanocapsules $(17 \mathrm{ml} / \mathrm{kg})$ or meloxicam-loaded nanocapsules $(5 \mathrm{mg} / \mathrm{kg})$ or free meloxicam $(5 \mathrm{mg} / \mathrm{kg})$. Treatments were performed on alternating days, until the end of the experimental protocol. In the fourteenth day, kinases activities were performed. Amyloid- $\beta$ did not change the kinases activity in the hippocampus and cerebral cortex of mice. However, free meloxicam decrease the creatine kinase activity in mitochondrial-rich fraction in the group induced by amyloid- $\beta$, but for the cytosolic fraction, it has raised in the activity of pyruvate kinase activity in cerebral cortex. Further, meloxicam-loaded nanocapsules administration reduced adenylate kinase activity in the hippocampus of mice injected by amyloid- $\beta$. In conclusion we observed absence in short-term effects in kinases activities of energy metabolism in mice hippocampus and cerebral cortex using amyloid- $\beta$ peptide model. These findings established the foundation to further study the kinases in phosphoryltransfer network changes observed in the brains of patients post-mortem with Alzheimer's disease.
\end{abstract}

Key words: Alzheimer's disease, nanoparticles, meloxicam, energetic metabolism, phosphoryltransfer network.

\section{INTRODUCTION}

Alzheimer's disease (AD) is the most common form of dementia and cognitive impairment (Cai et al. 2012), (Garcez et al. 2015). AD is characterized by accumulations of amyloid-beta $(\mathrm{a} \beta)$ pep-

Correspondence to: Cristiane Luchese

E-mail: cristiane_luchese@yahoo.com.br tide known as plaques and neurofibrillary tangles composed of the microtubule protein tau and synaptic and neuronal loss in several areas of the brain (Cai et al. 2012). Moreover, an essential feature of $\mathrm{AD}$ is implicated in synaptic dysfunction, dendritic spine loss, excitotoxicity and destabilization of neural networks that are considered major cellular 
mechanisms (Isono et al. 2013). Several researches have shown alterations in brain energy metabolism are associated with neurodegenerative disorders (Beal 1995, 2000), (Bubber et al. 2005), (Zahid et al. 2014). Abnormal hyperphosphorylation of tau have been associated with the activation of several kinases (Park et al. 2012). In fact, a $\beta$-peptide aggregates, it generates reactive oxygen species that can induce membrane lipid peroxidation in neurons (Mattson et al. 2002). This fact causes in impairment function of membrane ion-motive ATPases and glucose transporter proteins, which, in turn, disrupts cellular ion homeostasis and energy metabolism (Mattson et al. 2002).

Previous reports have shown energy metabolism related enzymes were frequently altered in AD (Brooks et al. 2007), (Liang et al. 2008). The thiol-containing enzymes, as kinases, are crucial for brain energy metabolism and function, and their deficiency is associated to neurodegenerative diseases. Creatine kinase (CK), pyruvate kinase (PK), and adenylate kinase (AK), which are thiolcontaining enzymes involved in the phosphoryltransfer network, are critical for energy metabolism in almost all mammalian tissues (De Franceschi et al. 2013). CK is used as an indicator of various physiological abnormalities, such as the determination of brain damage. CK has been shown to have a lower activity in AD (David et al. 1998). Indeed, enzyme oxidation, such CK in cellular metabolism, has been involved in the neurodegeneration mechanism of AD brain (Castegna et al. 2002). Besides, creatine, a product of $\mathrm{CK}$, is considered a neuroprotective agent in animal models of neurodegenerative diseases (Bortoluzzi et al. 2014).

Regarding to PK, this enzyme is crucial enzyme of glucose metabolism, and main pathway that provides energy for brain function (Gemelli et al. 2013). Pyruvate, an endogenous metabolite this pathway, can work as an anti-toxicity agent and it has been shown protective role in central nervous system neurons, protecting them against excitotoxic and metabolic insult (Bortoluzzi et al. 2014).
AK catalyzes the nucleotide phosphoryl exchange reaction maintain the consistent concentration and fixed ratio of adenine nucleotides. This is the major regulator of energetic, metabolic monitoring and cellular process in a living cell (Park et al. 2012). However, the role of AK expressed in the brain, especially in neurodegenerative disease, is not understood yet (Park et al. 2012). Moreover, the expression levels of AK markedly elevated in hippocampal neurons of AD patients and $\mathrm{Tg} 2576$ and APP-J20 AD mouse model and it has found AK expression increased in the cortical neurons after exposure to a $\beta$ (Park et al. 2012).

Several clinical studies indicated nonsteroidal anti-inflammatory drugs (NSAIDs) could reduce the prevalence of AD (Moore and O'Banion 2002), (Galimberti et al. 2003), (Townsend and Pratico 2005). Nevertheless, meloxicam is a NSAID that poorly crossed the blood-brain barrier (BBB), thereby limiting the use of this drug for treatment in neurodegenerative disorders (Carvey et al. 2009). In this way, our previous studies demonstrated meloxicam-loaded nanocapsules (M-NC) prevented $A D$ induced by a $\beta$ in mice (Ianiski et al. 2012). Besides, Bernardi et al. (2012), using another type of NSAID, the indomethacin-loaded lipid-core nanocapsules, have shown strong evidence that neuroinflammation triggered negatively modulates in vitro and in vivo caused by a $\beta$ culminating in the amelioration of synaptic integrity, cell survival, and cognitive performance. Therefore, nanoparticles represent very promising drug-delivery systems for the prevention and treatment of various diseases (Khayata et al. 2012).

Considering that there are not publications on phosphoryltransfer network in AD model induced by $\mathrm{a} \beta$ (25-35) in mice and $\mathrm{AD}$ is a prevalent neurodegenerative disease worldwide, we sought to investigate the involvement in activities of enzymes CK, AK and PK in the hippocampus and cerebral cortex of AD model by a $\beta$ (25-35) in mice, to evaluate in this model the ability to change these 
enzymes. Moreover, it was investigated the M-NC ability to restore these possible changes too.

\section{MATERIALS AND METHODS}

\section{CHEMiCALS}

$\mathrm{a} \beta$ (fragment 25-35) was dissolved in sterile filtered water and aggregated by incubation at $37{ }^{\circ} \mathrm{C}$ for 4 days before use and was purchased from Sigma (St. Louis, MO, USA). a $\beta$ (fragment 25-35) is the most toxic (Vitvitsky et al. 2012). All other chemicals and solvents used were of analytical or pharmaceutical grade.

Suspensions of M-NC were prepared by interfacial deposition method of preformed polymer adapted from Fessi et al. (1989), at a concentration of $0.3 \mathrm{mg} / \mathrm{ml}$. Aqueous phase was composed of water and polysorbate 80 . Organic phase was composed by meloxicam, poly- $\varepsilon$-caprolactone, sorbitan monostearate, caprylic/capric triglyceride and acetone. Organic phase was added under magnetic stirring into an aqueous phase. Suspensions of blank nanocapsules (B-NC) were prepared using the same protocol of suspensions above cited for M-NC, however, without the presence of drug. For free meloxicam (M-F) solution, meloxicam was dissolved in sorbitan monostearate, polysorbate and water.

These nanocapsules were characterized using photon correlation spectroscopy. Samples were diluted in Milli-Q water (1:500) and the analysis was performed at $25^{\circ} \mathrm{C}$, using a Zetasizer ${ }^{\circledR}($ Nanoseries, Malvern, UK). For encapsulation efficacy, it was used high performance liquid chromatography, showing around $98 \%$. Each sample was analyzed in triplicate. All parameters did not demonstrate significant difference. Physical-chemical analyses demonstrated that the particle diameter was 247 $\pm 9 \mathrm{~nm}$ and $212 \pm 10 \mathrm{~nm}$ for M-NC and B-NC, respectively, and polydispersity index was $0.14 \pm$ 0.02 for M-NC and $0.10 \pm 0.01$ for B-NC. The zetapotential was $-36.4 \pm 4.4 \mathrm{mV}$ for $\mathrm{M}-\mathrm{NC}$ and $-35.0 \pm$ $2.5 \mathrm{mV}$ for B-NC.
ANIMALS

In the present study, we used male Swiss mice $(20-25 \mathrm{~g})$ of 5 weeks old that were obtained from a local breeding colony. They were kept on a 12-12 $\mathrm{h}$ light/dark cycle in acclimatized room at constant temperature $\left(22 \pm 2{ }^{\circ} \mathrm{C}\right)$ and had free access to water and commercial chow (Guabi, RS, Brazil) containing $20.5 \%$ protein (predominantly soybean supplemented with methionine), $54 \%$ carbohydrate, $4.5 \%$, fiber $4 \%$, lipid $7 \%$ ash and $10 \%$ moisture. We applied strict ethical criteria in our study to minimize the pain and suffering. The animals were used according to the guidelines of the Committee on Care and Use of Laboratory Animals of the Franciscan University Center of Santa Maria, Brazil, under number 019/2012.

\section{EXPERIMENTAL PROTOCOL}

One day before initiating treatments, mice were randomly divided into two groups, where one group received a $\beta$ (fragment 25-35) aggregated form (3 $\mathrm{nmol} / 3 \mu \mathrm{l} /$ per site, intracerebroventricular (i.c.v.)) (Ianiski et al. 2012). Other group received saline ( $3 \mu 1 /$ per site i.c.v.). I.c.v. infusion of a $\beta$ or vehicle (saline) was administered using a microsyringe with a 28-gauge stainless-steel needle $3.0 \mathrm{~mm}$ long (Hamilton) according to previous report (Haley and McCormick 1957). All animals were anesthetized with ketamine/xylazine $(80 / 10 \mathrm{mg} / \mathrm{kg}$, intraperitoneally). Mice exhibited normal behavior within 1 min after injection.

After this, each group was randomly divided into 3 groups of six animals each. One day after infusion a $\beta$ or saline, the treatments with B-NC, $\mathrm{M}-\mathrm{NC}$ or M-F intragastrically (i.g.) via gavage were initiated. The treatments were performed each other day, until the end of the experimental protocol (Ianiski et al. 2012). The volume used for B-NC (17 $\mathrm{ml} / \mathrm{kg}$ body weight) and equivalent dose of $\mathrm{M}-\mathrm{NC}$ or M-F ( $5 \mathrm{mg} / \mathrm{kg}$ body weight) was chosen based on a previous study (Ianiski et al. 2012, 2016), 
(Villalba et al. 2014). Mice belonging to a $\beta$ and Sham groups received the suspension containing B-NC. Animals of M-NC and M-NC induced by a $\beta$ groups received the suspension containing M-NC. Animals belonging to M-F and M-F induced by $\mathrm{a} \beta$ groups were treated with suspension containing M-F. After fourteenth day of a $\beta$ (fragment 25-35) injection, mice were euthanized and hippocampus and cortex were removed for determination of CK, $\mathrm{AK}$ and PK activities (Figure 1).

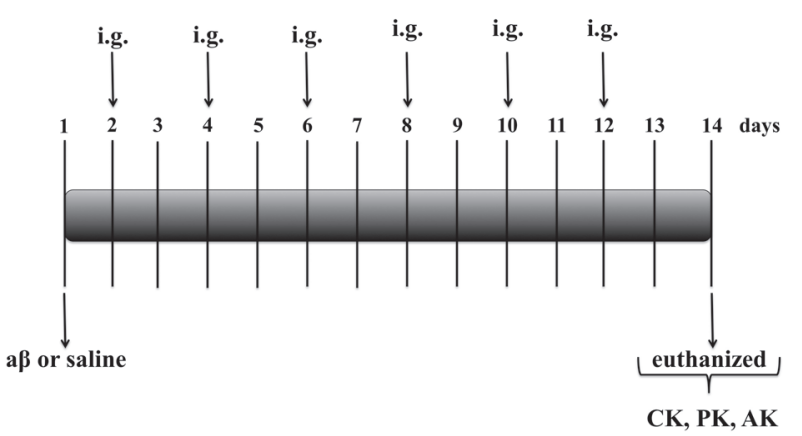

Figure 1 - Schema of experimental protocol: mice received $\mathrm{a} \beta$ (fragment 25-35) aggregated form or vehicle (saline) intracerebroventricular (i.c.v.). Intragastrically (i.g.) treatments were performed each other day, until the end of the experimental protocol. In the fourteenth day, mice were euthanized and hippocampus and cerebral cortex were removed for determination of creatine kinase (CK), adenylate kinase (AK) and pyruvate kinase $(\mathrm{PK})$ activities.

\section{TISSUE PREPARATION}

For assays of the enzymes CK, AK and PK, the cerebral cortex and hippocampus were homogenized in buffer $(0.32 \mathrm{M}$ sucrose, $1 \mathrm{mM}$ EGTA, $10 \mathrm{mM}$ Tris- $\mathrm{HCl}, \mathrm{pH}$ 7.4). The homogenate was centrifuged at $800 \mathrm{x} \mathrm{g}$ for $10 \mathrm{~min}$ at $4{ }^{\circ} \mathrm{C}$. Part of the supernatant was used for determination of AK activity, the other part of the supernatant was centrifuged at $10,000 \mathrm{xg}$ for $15 \mathrm{~min}$ at $4{ }^{\circ} \mathrm{C}$. The supernatant of this second centrifugation was collected for determination of PK and cytosolic CK activities. The pellet was washed twice with the same homogeneization buffer, and resuspended in $100 \mathrm{mM}$ Trizma, $15 \mathrm{mM} \mathrm{MgSO}_{4}$ buffer, $\mathrm{pH} 7.5$ to determinate mitochondrial CK activity.

\section{CK activity}

The creatine formed was estimated according to the colorimetric method of Hughes (1962). CK activity was assayed in the reaction mixture contained 65 $\mathrm{mM}$ Tris- $\mathrm{HCl}$ buffer, $\mathrm{pH}$ 7.5, $7 \mathrm{mM}$ phosphocreatine, $9 \mathrm{mM} \mathrm{MgSO}_{4}$, and $1 \mu \mathrm{g}$ of protein (cytosolic or mitochondrial-rich fraction), in a final volume of $0.1 \mathrm{ml}$. After $10 \mathrm{~min}$ of pre-incubation at $37^{\circ} \mathrm{C}$, the reaction was started by the addition of $0.3 \mu \mathrm{mol}$ of adenosine diphosphate (ADP). The reaction was stopped after $10 \mathrm{~min}$ by the addition of $1 \mu \mathrm{mol}$ of p-hydroxymercuribenzoic acid. The color was developed by the addition of $0.1 \mathrm{ml} 2 \%$ a-naphthol and $0.1 \mathrm{ml} 0.05 \%$ diacetyl, in a final volume of 1 $\mathrm{ml}$ and the samples were read after $20 \mathrm{~min}$ at 540 $\mathrm{nm}$ in a spectrophotometer. Results were expressed as $\mu \mathrm{mol}$ creatine. $\mathrm{min}^{-1}$.mg protein ${ }^{-1}$.

\section{AK activity}

AK activity was measured with a coupled enzyme assay with hexokinase (HK) and glucose 6-phosphate dehydrogenase (G6PD), according to Dzeja et al. (1999). The reaction mixture contained 100 mM KCl, 20 mM HEPES, $20 \mathrm{mM}$ glucose, $4 \mathrm{mM}$ $\mathrm{MgCl}_{2}, 2 \mathrm{mM}$ nicotinamide adenine dinucleotide phosphate $\left(\mathrm{NADP}^{+}\right), 1 \mathrm{mM}$ ethylenediamine tetraacetic acid (EDTA), $4.5 \mathrm{U} / \mathrm{ml}$ of $\mathrm{HK}, 2 \mathrm{U} / \mathrm{ml}$ of G6PD, and $1 \mu \mathrm{g}$ of protein homogenate. The reaction was initiated by the addition of $2 \mathrm{mM}$ ADP and the reduction of $\mathrm{NADP}^{+}$and then was followed at $340 \mathrm{~nm}$ for $3 \mathrm{~min}$ in a spectrophotometer. The results were expressed in $\mu \mathrm{mol}$ adenosine triphosphate (ATP) formed $\mathrm{min}^{-1} . \mathrm{mg}$ protein ${ }^{-1}$.

\section{PK activity}

PK activity was assayed essentially as described by Leong et al. (1981). The incubation medium consisted of $0.1 \mathrm{M}$ Tris/ $\mathrm{HCl}$ buffer, $\mathrm{pH} 7.5,10 \mathrm{mM}$ $\mathrm{MgCl}_{2}, 0.16 \mathrm{mM} \mathrm{NADH}, 75 \mathrm{mM} \mathrm{KCl}, 5.0 \mathrm{mM}$ 
ADP, $7 \mathrm{U}$ of L-lactate dehydrogenase, $0.1 \%(\mathrm{v} / \mathrm{v})$ Triton X-100, and $10 \mu \mathrm{l}$ of supernatant, in a final volume of $0.5 \mathrm{ml}$. After $10 \mathrm{~min}$ of pre-incubation at $37{ }^{\circ} \mathrm{C}$, the reaction was started by the addition of $1 \mathrm{mM}$ phosphoenol pyruvate that was followed at $340 \mathrm{~nm}$ for $30 \mathrm{sec}$ in a spectrophotometer. All assays were performed at $25^{\circ} \mathrm{C}$. Results were expressed as $\mu \mathrm{mol}$ pyruvate. $\mathrm{min}^{-1}$.mg protein ${ }^{-1}$.

\section{Protein}

Protein content of each tissue fraction of hippocampus and cerebral cortex was determined by the method of Lowry et al. (1951), using serum bovine albumin as the standard.

STATISTICAL ANALYSIS

Data are expressed as mean \pm standard deviation (S.D.). Statistical analysis was performed using a one-way ANOVA followed by the Tukey's test.
Values of $p<0.05$ were considered statistically significant.

\section{RESULTS}

\section{CK ACTIVITY}

CK activities in mitochondrial-rich and cytosolic fraction did not show a significant differ between the groups $(p>0.05)$ in mice hippocampus (Figures $2 \mathrm{a}$ and $3 \mathrm{a})$.

CK activity in mitochondrial-rich fraction in cerebral cortex of mice demonstrated a significant decrease in $\mathrm{M}-\mathrm{F}$ induced by a $\beta$ group, when compared to the Sham group $(\mathrm{p}<0.05)$ (Figure $2 b)$. However, a $\beta, \mathrm{M}-\mathrm{NC}$ or M-F alone did not change $\mathrm{CK}$ activity in mitochondrial-rich fraction in the cerebral cortex of mice (Figure 2b). Furthermore, $\mathrm{CK}$ activity in cytosolic fraction in cerebral cortex of mice, did not show a significant differ between the groups $(p>0.05)$ (Figure 3b).
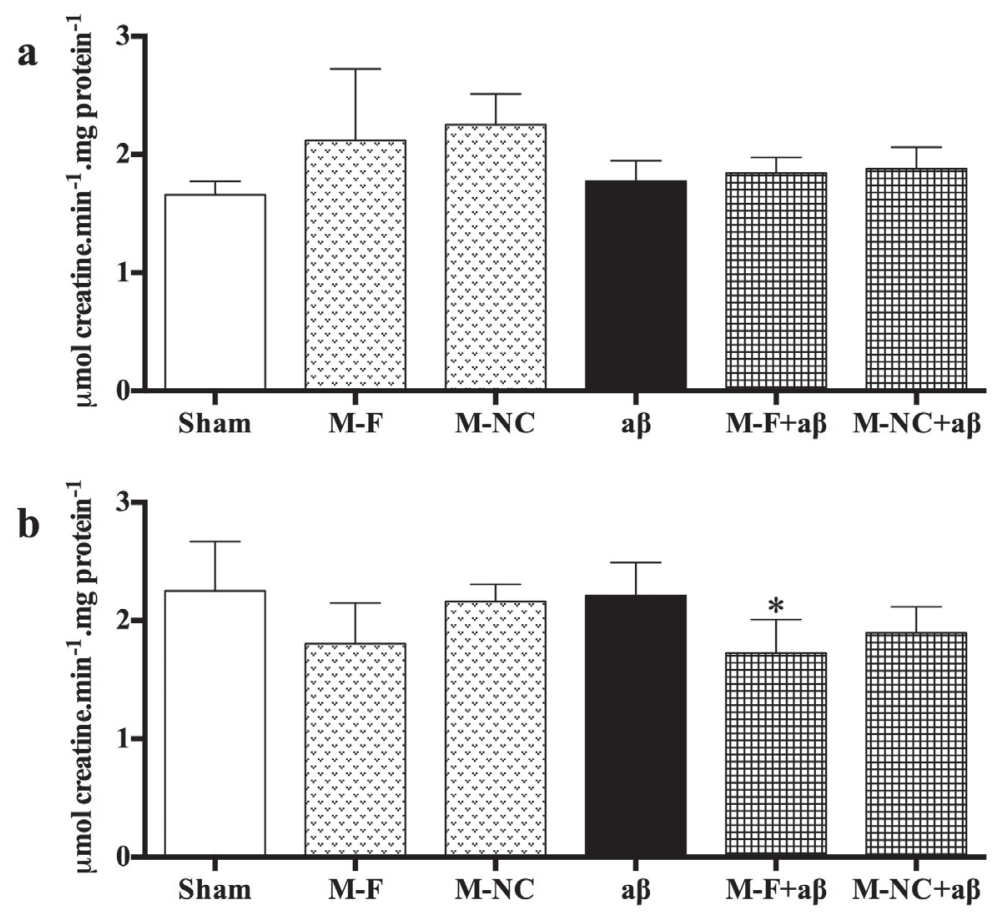

Figure 2 - a $\beta$, meloxicam-loaded nanocapsules (M-NC) and free meloxicam (M-F) on mitochondrial-rich fraction creatine kinase activity. Suspension containing blank nanocapsules (Sham). (a) $\mu \mathrm{mol}$ creatine. $\mathrm{min}^{-1}$.mg protein ${ }^{-1}$ in hippocampus mice. (b) $\mu \mathrm{mol}$ creatine. $\mathrm{min}^{-1}$.mg protein ${ }^{-1}$ in cerebral cortex mice. Data represent mean \pm standard deviation, $n=6$ /group. $(*) p<0.05$ as compared to the sham group. 

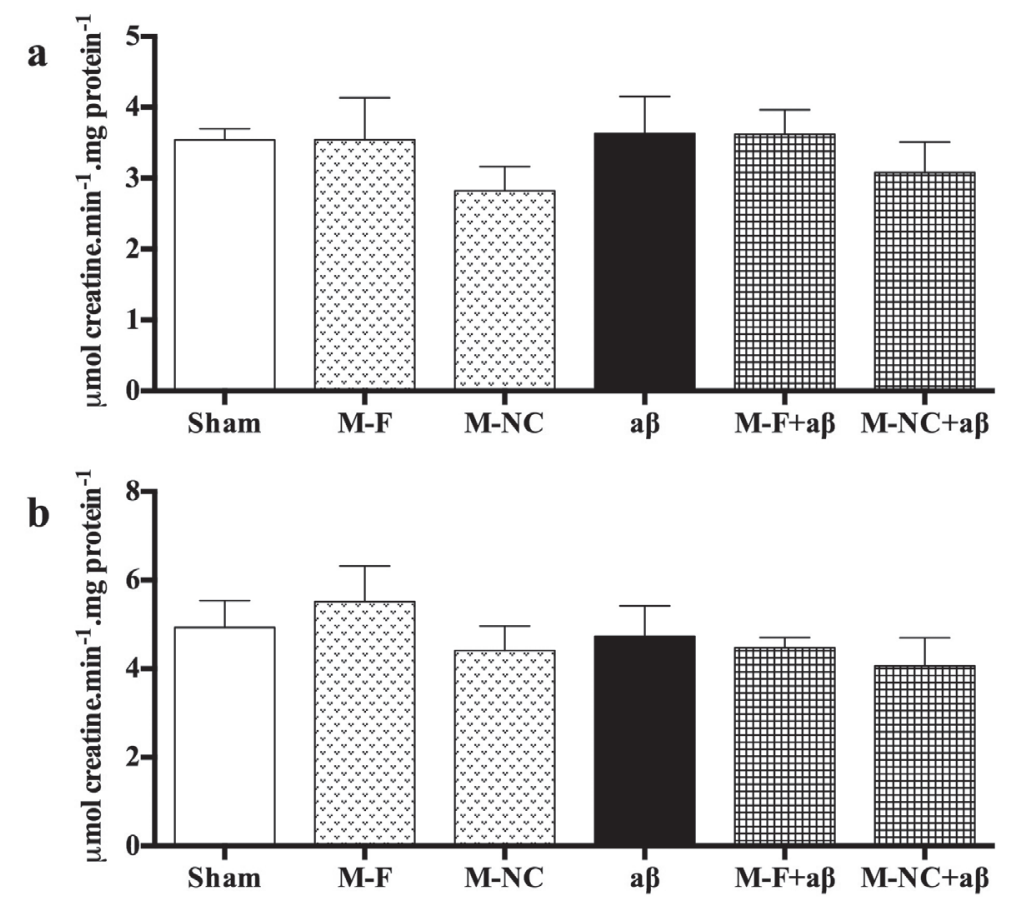

Figure 3 - a $\beta$, meloxicam-loaded nanocapsules (M-NC) and free meloxicam (MF) on cytosolic fraction creatine kinase activity. Suspension containing blank nanocapsules (Sham). (a) $\mu \mathrm{mol}$ creatine. $\mathrm{min}^{-1} \cdot \mathrm{mg}$ protein ${ }^{-1}$ in hippocampus mice. (b) $\mu \mathrm{mol}$ creatine. $\mathrm{min}^{-1} . \mathrm{mg}$ protein ${ }^{-1}$ in cerebral cortex mice. Data represent mean \pm standard deviation, $\mathrm{n}=6$ /group.

\section{AK ACTIVITY}

AK activity in the hippocampus demonstrated a significant decrease in M-NC induced by a $\beta$ group, when compared to the Sham group $(\mathrm{p}<0.01)$ (Figure 4a). However, a $\beta$, M-NC or M-F alone did not change the $\mathrm{AK}$ activity in mice hippocampus.

Besides AK activity in cortex of mice, did not show significant difference between the groups $(\mathrm{p}$ $>0.05$ ) (Figure 4b).

\section{PK ACTIVITY}

PK activity in cytosolic fraction did not show significant difference between the groups $(p>0.05)$ in the hippocampus of mice (Figure 5a).

PK activity in cytosolic fraction of cerebral cortex in mice demonstrated that M-F significantly increased in PK activity, when compared to the Sham group $(\mathrm{p}<0.001)$ (Figure $5 b)$. Nonetheless, $\mathrm{a} \beta$ and $\mathrm{M}-\mathrm{NC}$ alone did not change the PK activity in cytosolic fraction in the cerebral cortex of mice (Figure 5b).

\section{DISCUSSION}

In the present study, we have assessed, for the first time, the effects of three kinase activities CK, $\mathrm{AK}$ and $\mathrm{PK}$ of energy metabolism and treatments with B-NC, M-F and M-NC, in hippocampus and cerebral cortex of AD model induced by a $\beta(25-35)$ in mice. Evidence suggests a critical role in changes in brain energy metabolism in the pathogenesis of cognitive disorders (Kapogiannis and Mattson 2011). However, studies about the involvement of these enzymes in the AD diseases are limited.

Surprisingly, we observed absence in shortterm effects in kinases activities of energy metabolism in mice hippocampus and cerebral cortex using a $\beta$ peptide (25-35) model. Importantly, cerebral 

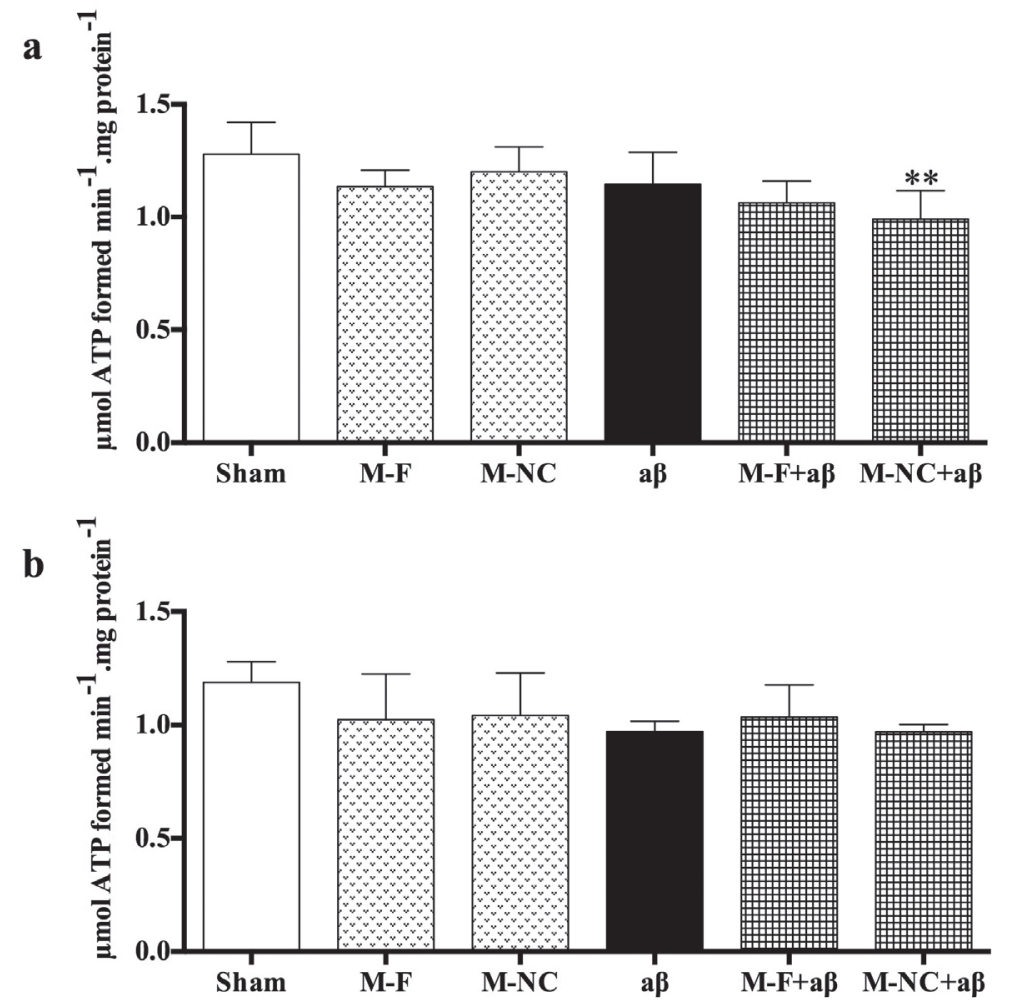

Figure 4 - a $\beta$, meloxicam-loaded nanocapsules (M-NC) and free meloxicam (M-F) on cytosolic fraction adenylate kinase activity. Suspension containing blank nanocapsules (Sham). (a) $\mu$ mol ATP formed $\min ^{-1} . \mathrm{mg}$ protein ${ }^{-1}$ in hippocampus mice. (b) $\mu \mathrm{mol}$ ATP formed $\mathrm{min}^{-1}$.mg protein ${ }^{-1}$ in cerebral cortex mice. Data represent mean \pm standard deviation, $n=5$ /group. $(* *) p<0.01$ as compared to the sham group.

cortex and hippocampus were chosen based on previous studies that demonstrated alterations on these structures in patients with AD (David et al. 1998), (Aksenov et al. 2000), (Clark et al. 2000), (Balderas et al. 2008). Moreover, hippocampus is a cerebral structure essential for memory processing (Clark et al. 2000), (Balderas et al. 2008), (Bernardi et al. 2012). Some studies suggest that altered energy metabolism plays roles in the pathogenesis of AD (Behl 1999), seeing that CK is involved in high-energy production, thus affecting ATP synthesis. On the other hand, in this study, there was no difference of cytosolic and mitochondrial CK activity in the two brain structures. Researches have reported reduction on the CK activity in the cerebral cortex of humans (age between 70 to 85 years old) with $\mathrm{AD}$ in post-morten assays (Aksenov et al. 2000). Limitations must be taken into account when interpreting the results of this study. First, this AD model induced by a $\beta(25-35)$ is not a clinical representation of most human brain injuries. Thereby, it is known that animal models do not totally reproduce human diseases in their complexity. Furthermore, the substances known to accumulate in human disease may be studied individually or associated against adequate controls (Bortoluzzi et al. 2014).

The deposition of a $\beta$ in mice could be used as an animal model for the study of AD because it is a well-characterized model (Choi et al. 2014), (Pedrós et al. 2014). In fact, several studies have shown that $\mathrm{AD}$ is induced by injections of $\mathrm{a} \beta(25-35)$ into the brains of mice and it causes various biological effects (Tsunekawa et al. 2008), (Ianiski et al. 2012), 

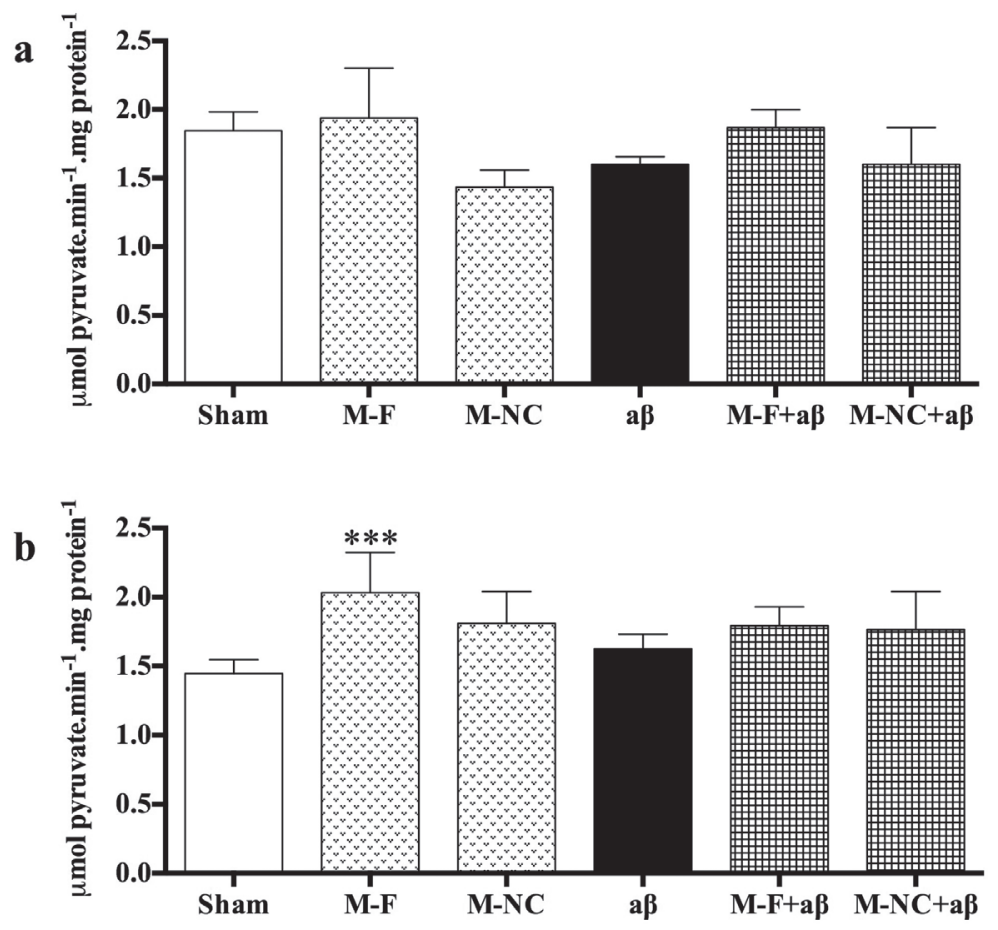

Figure 5 - a $\beta$, meloxicam-loaded nanocapsules (M-NC) and free meloxicam (M-F) on cytosolic fraction pyruvate kinase activity. Suspension containing blank nanocapsules (Sham). (a) $\mu \mathrm{mol}$ pyruvate. $\mathrm{min}^{-1} . \mathrm{mg} \mathrm{protein}^{-1}$ in hippocampus mice. (b) $\mu \mathrm{mol}$ pyruvate. $\mathrm{min}^{-1} . \mathrm{mg}$ protein ${ }^{-1}$ in cerebral cortex mice. Data represent mean \pm standard deviation, $\mathrm{n}=5$ /group. $(* * *) \mathrm{p}<0.001$ as compared to the sham group.

(Choi et al. 2014), (Detrait et al. 2014), thus this model has been widely used for studies associated with AD. Therefore, $\mathrm{a} \beta(25-35)$ injected animals are useful models for understanding various problems of $\mathrm{AD}$, such as the pathogenesis and progression of changes, and for evaluating new therapeutic agents for AD (Tsunekawa et al. 2008), (Choi et al. 2014). We believe that the time interval of a $\beta$ injection in our research was not enough to cause changes, and consequently it was not possible to see the change in CK, AK and PK activities. Despite the peptide a $\beta$ be considered a toxic substance (Tsunekawa et al. 2008), (Ianiski et al. 2012), (Choi et al. 2014), (Detrait et al. 2014), and, for this model is already reported that the administration of the same cause learning and memory deficits, neuronal loss, intense cellular accumulation and chromatolysis and oxidative stress was increased in mice (Ianiski et al. 2012), definitely this experimental design did not affect these three important kinases of brain energy metabolism.

For mice cerebral cortex, we observed a significant decrease in CK activity on the M-F induced by a $\beta$ group in mitochondrial-rich fraction. A study has shown that various compounds may affect mitochondrial bioenergetics (Moreland 1994). In fact, it is known that compounds as meloxicam are uncoupled (Mahmud et al. 1996), promote the increase in permeability of the inner mitochondrial membrane to protons. Thus, there is electrons transfer and, consequently, does not occur synthesis of ATP (Tzagoloff 1982), (Moreland 1994). Moreover, a decrease in CK activity is one of the biochemical markers of the central nervous system cell damage in age-related neurodegenerative diseases, including AD (Hensley et al. 1995), (Aksenova et al. 
1999), (Aksenov et al. 2000). The decrease on the CK activity and content in brain of AD correlates well with the hallmarks of neurodegeneration in severely affected regions (Hensley et al. 1995).

Furthermore, in cytosolic fraction of mouse cerebral cortex, it was observed that M-F significantly increased the PK activity. An in vitro study demonstrated that a $\beta$ reduced the PK activity in erythrocytes of old rats, but not in erythrocytes of young rats, demonstrating that the age interferes in the effects of glycolytic and antioxidant enzymes in AD (Tikhonova et al. 2014). Nevertheless, we noted a significant decrease in $\mathrm{M}-\mathrm{NC}$ induced by a $\beta$ group on the AK activity in mice hippocampus.

The coupling of spatially separated intracellular ATP-producing and ATP-consuming processes is fundamental to the bioenergetics of living organisms and important to maintain a broad range of cellular activities (Dzeja and Terzic 2003). However, spatially arranged intracellular enzymatic networks are necessitated, because it seems to be insufficient to fulfill all cellular energetic needs (Dzeja et al. 2000). Thereby to support high-energy phosphoryltransfer and signal communication between ATP-generating and ATP-consuming/ATP-sensing processes, these networks need to be catalyzed by CK, AK and enzymes of the glycolysis pathway, in especial PK (Dzeja et al. 1998), (Dzeja and Terzic 2003), (Wallimann et al. 1992). For maintaining the cellular energy homeostasis is indispensable the network between the enzymatic capacities, isoform distribution and the dynamics of phosphoryl flux through the integrated phosphoryltransfer systems tightly correlate with cellular functions, thus indicating a critical role of such networks in efficient energy transfer and distribution (Dzeja and Terzic 2003).

The ATP formation rate calculated from the cerebral metabolic rates of oxidized glucose and oxygen is reduced in the brains greater than $50 \%$ of advanced AD patients (Hoyer 1992). A diminished activity of a single enzyme of the phoryltransfer network is rather well tolerated. However, a decrease in the activity of two or more enzymes of this network may compromise the brain development (Pietz et al. 2003), (Rojas et al. 2012). In addition, results of observational studies and trials might differ because different NSAIDs have different effects on AD (Gasparini et al. 2004).

Previously, it was reported that nanocapsules showed effective delivery of drugs to the brain and to inflamed tissues (Frozza et al. 2010), (Bernardi et al. 2012), (Ianiski et al. 2012, 2016), (Villalba et al. 2014). In this way, some characteristics of nanoparticulated systems, such as the carrier size, the polymer type, as well as their surface features, might induce steric stabilization of nanoparticles, inhibiting protein binding and increasing the blood circulation time (Brioschi et al. 2007), (Bernardi et al. 2009), (Kreuter 2014), (Voigt et al. 2014). Moreover, nanocapsules can accumulate in inflamed tissues due to the greater microvascular permeability in those sites (Bernardi et al. 2009).

The purpose of this study was to investigate the role of the enzymes CK, AK and PK in hippocampus and cerebral cortex of AD model induced by a $\beta$ (25-35) in mice and to determine whether the broad range of impairments that are observed in brain of AD could be, at least in part, reproduced and used in this animal model. As in previous studies, we used similar or slightly different mouse models of $A D$ induced by $a \beta$ where there were alterations in behaviors and biochemical analysis (Ianiski et al. 2012), (Detrait et al. 2014). Surprisingly, we observed absence in short term effects in kinase activity of energy metabolism in mice hippocampus and cerebral cortex using a $\beta$ peptide (25-35) model. This demonstrates that AD model induced by a $\beta$ (25-35) in the short term in mice is not a determining factor to reproduce the enzymatic changes of CK, AK and PK observed in the brains of patient's post-mortem with AD. In summary, these findings established the foundation to further study the kinases in phosphoryltransfer 
network changes observed in the brains of patients post-mortem with AD.

\section{ACKNOWLEDGMENTS}

The financial support by Fundação de Amparo à Pesquisa do Estado do Rio Grande do Sul (FAPERGS) (\#1924-2551/13-1), Coordenação de Aperfeiçoamento de Pessoal de Nível Superior (CAPES) and Centro Universitário Franciscano is gratefully acknowledged.

\section{RESUMO}

Considerando que a doença de Alzheimer é uma doença neurodegenerativa prevalente em todo o mundo, buscou-se investigar o envolvimento da atividade de três quinases: creatinaquinase, piruvatoquinase e adenilatoquinase no hipocampo e no córtex cerebral em um modelo da doença de Alzheimer. Os camundongos Swiss, machos, adultos, receberam $\beta$-amiloide ou solução salina. Um dia depois, os camundongos foram tratados com nanocápsulas vazias $(17 \mathrm{ml} / \mathrm{kg})$ ou nanocápsulas contendo meloxicam $(5 \mathrm{mg} / \mathrm{kg}$ ) ou meloxicam livre ( $5 \mathrm{mg} / \mathrm{kg})$. Os tratamentos foram realizados em dias alternados, até o final do ptotocolo experimental. No décimo quarto dia, as atividades das quinases foram avaliadas. $A \beta$-amiloide não alterou a atividade das quinases no hipocampo e no córtex cerebral dos camundongos. No entanto, o meloxicam livre diminuiu a atividade da creatinaquinase na fração mitocondrial no grupo induzido pela $\beta$-amiloide, mas na fração citosólica observou-se um aumento na atividade da piruvatoquinase no córtex cerebral. Além disso, o tratamento com as nanocápsulas contendo meloxicam diminuiu a atividade da adenilatoquinase no hipocampo dos camundongos induzidos pela $\beta$-amiloide. Em conclusão, observamos ausência de efeitos de curto prazo nas atividades das quinases do metabolismo energético no hipocampo e no córtex cerebral de camundongos, no modelo induzido com o peptídeo amiloide- $\beta$. Esses resultados estabeleceram uma base para um estudo mais aprofundado das quinases em alterações na rede de fosforiltransferência observadas nos cérebros de pacientes pós-morte com a doença de Alzheimer.
Palavras-chave: doença de Alzheimer, nanopartículas, meloxicam, metabolismo energético, rede de fosforiltransferência.

\section{REFERENCES}

AKsenov M, AKsenova M, Butterfield DA AND MARKESBERY WR. 2000. Oxidative modification of creatine kinase BB in Alzheimer's disease brain. J Neurochem 74: 2520-2527.

AKSENOVA MV, AKSENOV MY, PAYNE RM, TROJANOWSKI JQ, SCHMIDT KL, CARNEY JM, BUTTERFIELD DA AND MARKESBERY WR. 1999. Oxidation of cytosolic proteins and expression of creatine kinase $\mathrm{BB}$ in frontal lobe in different neurodegenerative disorders. Dement Geriatr Cogn Disord 10: 158-165.

BALDERAS I, RODRIGUEZ-ORTIZ CJ, SALGADO-TONDA P, CHAVEZ-Hurtado J, MCGAUGH JL AND BERMUdEZRATTONI F. 2008. The consolidation of object and context recognition memory involve different regions of the temporal lobe. Learn Mem 15: 618-624.

BEAL MF. 1995. Aging, energy, and oxidative stress in neurodegenerative diseases. Ann Neurol 38: 357-366.

BEAL MF. 2000. Energetics in the pathogenesis of neurodegenerative diseases. Trends Neurosci 23: 298-304.

BEHL C. 1999. Alzheimer's disease and oxidative stress: implications for novel therapeutic approaches. Prog Neurobiol 57: 301-323.

Bernardi A, Frozza RL, MEneghetti A, Hoppe JB, Battastini AMO, Pohlmann AR, Guterres SS AND SALBEGO CG. 2012. Indomethacin-loaded lipidcore nanocapsules reduce the damage triggered by a $\beta$ 1-42 in Alzheimer's disease models. Int J Nanomedicine 7: 4927-4942.

Bernardi A, Zilberstein A, JAgER E, CAMpos MM, Morrone FB, Calixto JB, POHLMAnN AR, GUTERRES SS AND BATTASTINI AMO. 2009. Effects of indomethacin-loaded nanocapsules in experimental models of inflammation in rats. Br J Pharmacol 158: 1104 1111.

BORTOLUZZI VT, FRANCESCHI ID, RIEGER E AND WANNMACHER CMD. 2014. Co-administration of creatine plus pyruvate prevents the effects of phenylalanine administration to female rats during pregnancy and lactation on enzymes activity of energy metabolism in cerebral cortex and hippocampus of the offspring. Neurochem Res 39: 1594-1602.

BRIOSCHI A, ZENGA F, ZARA CP, GASCO MR, DUCATI A AND MAURO A. 2007. Solid lipid nanoparticles: could they help to improve the efficacy of pharmacologic treatments for brain tumors? Neurolog Res 29: 324-330.

BROOKS WM, LYNCH PJ, INGLE CC, HATTON A, EMSON PC, FAULL RL AND STARKEY MP. 2007. Gene expression 
profiles of metabolic enzyme transcripts in Alzheimer's disease. Brain Res 1127: 127-135.

Bubber P, Haroutunian V, Fisch G, Blass JP AND GIBSON GE. 2005. Mitochondrial abnormalities in Alzheimer brain: mechanistic implications. Ann Neurol 57: 695-703.

CAi H, CONG WN, Ji S, Rothman S, Maudsley S AND MARTIN B. 2012. Metabolic dysfunction in Alzheimer's disease and related neurodegenerative disorders. Curr Alzheimer Res 9: 5-17.

CARVEY PM, HENDEY B AND MONAHAN AJ. 2009. The blood-brain in neurodegenerative disease: a rhetorical perspective. J Neurochem 111: 291-314.

Castegna A, AKsenov M, AKsenova M, Thongboonkerd V, KLein JB, Pierce WM, Booze R, MARKeSBERY WR AND BUtTERFIELD DA. 2002. Proteomic identification of oxidatively modified proteins in alzheimer's disease brain. Part I: creatine kinase bb, glutamine synthase, and ubiquitin carboxy-terminal hydrolase L-1. Free Radic Biol Med 33: 562-571.

Choi YY, MaEda T, Fujil H, Yokozawa T, Kim HY, CHO EJ AND SHibAmoto T. 2014. Oligonol improves memory and cognition under an amyloid $\beta 25-35$-induced Alzheimer's mouse model. Nutr Res 34: 595-603.

CLARK RE, ZOLA SM AND SQUIRE LR. 2000. Impaired recognition memory in rats after damage to the hippocampus. J Neurosci 20: 8853-8860.

DAVID S, SHOEMAKER M AND HALEY BE. 1998. Abnormal properties of creatine kinase in Alzheimer's disease brain: Correlation of reduced enzyme activity and active site photolabeling with aberrant cytosol-membrane partitioning. Mol Brain Res 54: 276-287.

DE Franceschi ID, RIEGER E, VARGAS AP, RoJAS DB, CAMPOS AG, RECH VC, FEKSALR AND WANNMACHER CM. 2013. Effect of leucine administration to female rats during pregnancy and lactation on oxidative stress and enzymes activities of phosphoryltransfer network in cerebral cortex and hippocampus of the offspring. Neurochem Res 38: 632-643.

Detrait E, Maurice T, Hanon E, LeClercQ K AND LAMBERTY Y. 2014. Lack of synaptic vesicle protein SV2B protects against amyloid- $\beta 25-35$-induced oxidative stress, cholinergic deficit and cognitive impairment in mice. Behav Brain Res 271: 277-285.

DZEJA PP, REDFIELD MM, BURNETT JC AND TERZIC A. 2000. Failing energetics in failing hearts. Curr Cardiol Rep 2: 212-217.

DZEJA PP AND TERZIC A. 2003. Phosphotransfer networks and cellular energetics. J Exp Biol 206: 2039-2047.

DZEJA PP, VITKEVICIUS KT, REDFIELD MM, BURNETT JC AND TERZIC A. 1999. Adenylate kinase-catalyzed phosphotransfer in the myocardium: increased contribution in heart failure. Circ Res 84: 1137-1143.
DZEJA PP, ZELEZNIKAR RJ AND GOLDBERG ND. 1998. Adenylate kinase: kinetic behavior in intact cells indicates it is integral to multiple cellular processes. Mol Cell Biochem 184: 169-182.

FESSi H, PUISIEUX F, DEVISSAGUET JP, AMOURY N AND BENITA S. 1989. Nanocapsules formation by interfacial polymer deposition following solvent displacement. Int $\mathrm{J}$ Pharm 113: 1-4.

FrozZA RL, BERNARdi A, PAESE K, Hoppe JB, DA SilVA T, BATTASTINI AM, POHLMANN AR, GUTERRES SS AND SALBEGO C. 2010. Characterization of trans-resveratrolloaded lipid-core nanocapsules and tissue distribution studies in rats. J Biomed Nanotechnol 6: 694-703.

GALIMBERTI D, SCHOONEMBOO N, SCARPINI E AND SCHELTENS P. 2003. Chemokines in serum and cerebrospinal fluid of Alzheimer's disease patients. Ann Neurol 53: 547-548.

GARCEZ ML, FAlChetti ACB, Mina F AND BUDni J. 2015. Alzheimer's Disease associated with Psychiatric Comorbidities. An Acad Bras Cienc 87: 1461-1473.

GASPARINI L, ONGINI E AND WENK G. 2004. Non-steroidal antiinflammatory drugs (NSAIDs) in Alzheimer's disease: old and new mechanisms of action. J Neurochem 91: 521536.

Gemelli T, ANDRADE RB, Rojas DB, BONORINO NF, MAZZOLA PN, TORTORELli LS, FunChAL C, FilHO CSD AND WANNMACHER CMD. 2013. Effects of b-alanine administration on selected parameters of oxidative stress and phosphoryltransfer network in cerebral cortex and cerebellum of rats. Mol Cell Biochem 380: 161-170.

HALEY TJ AND MCCORMICK WG. 1957. Pharmacological effects produced by intracerebral injection of drugs in the conscious mouse. Br J Pharmacol Chemother 12: 12-15.

HENSLEY K ET AL. 1995. Brain regional correspondence between Alzheimer's disease histopathology and biomarkers of protein oxidation. J Neurochem 65: 21462156.

HOYER S. 1992. Oxidative energy metabolism in Alzheimer brain. Mol Chem Neuropathol 16: 207-224.

HuGHES BP. 1962. A method for the estimation of serum creatine kinase and its use in comparing creatine kinase and aldolase activity in normal and pathological sera. Clin Chim Acta 7: 597-603.

IANISKI FR, ALVES CB, SOUZA ACG, PINTON S, ROMAN SS, RHODEN CRB, ALVES MP AND LuCHESE C. 2012. Protective Effect of Meloxicam-loaded Nanocapsules against Amyloid- $\beta$ peptide-induced damage in mice. Behav Brain Res 230: 100-107.

IANISKI FR, SILVA FD, WILHELM EA, FERNANDES RS, ALVES MP, DuARTE MMMF AND LuCHESE C. 2016. Enhanced anti-inflammatory benefits of meloxicamloaded lipid-core nanocapsules in a mouse pleurisy model: 
A comparative study with a free form drug. J Appl Biomed 14: 105-112.

ISONO T ET AL. 2013. Amyloid- $\beta$ 25-35 induces impairment of cognitive function and long-term potentiation through phosphorylation of collapsin response mediator protein 2 . Neurosci Res 77: 180-185.

KAPOGIANNIS D AND MATTSON MP. 2011. Perturbed energy metabolism and neuronal circuit dysfunction in cognitive impairment. Lancet Neurol 10: 187-198.

KhaYATA N, ABDELWAHED W, CHEHNA MF, CHARCOSSET C AND FESSI H. 2012. Preparation of vitamin E loaded nanocapsules by the nanoprecipitation method: From laboratory scale to large scale using a membrane contactor. Int J Pharm 423: 419-427.

KREUTER J. 2014. Drug delivery to the central nervous system by polymeric nanoparticles: What do we know? Adv Drug Deliv Rev 71: 2-14.

LEONG SFLJ, LIM L AND CLARK JB. 1981. Energy-metabolizing enzymes in brain regions of adult and aging rats. $\mathrm{J}$ Neurochem 37: 1548-1556.

LIANG WS ET AL. 2008. Alzheimer's disease is associated with reduced expression of energy metabolism genes in posterior cingulate neurons. Proc Natl Acad Sci USA 105: 4441-4446.

LOWRY OH, ROSEBROUGH NJ, FARR AL AND RANDALL RJ. 1951. Protein measurement with the Folin phenol reagent. J Biol Chem 193: 265-275.

MAHMUD T, RAFI SS, SCOTT DL, WRIGGLESWORTH JM AND BJARNASON I. 1996. Nonsteroidal antiinflammatory drugs and uncoupling of mitochondrial oxidative phosphorylation. Arthritis Rheum 39: 1998-2003.

MATTSON MP, CHAN SL AND DUAN W. 2002. Modification of brain aging and neurodegenerative disorders by genes, diet, and behavior. Physiol Rev 82: 637-672.

MOORE AH AND O'BANION K. 2002. Neuroinflammation and anti-inflammatory therapy for Alzheimer's disease. Adv Drug Deliver Rev 54: 1627-1656.

MORELAND DE. 1994. Effects of toxicants on oxidative photophosphorylation. In: Hodgson E and Levi PE (Eds), Introduction to biochemical toxicology. Norwalk: Appleton and Lange, p. 345-366.

PARK H, KAM TI, KIM Y, CHOI H, GWON Y, KIM C, KOH JY AND JUNG YK. 2012. Neuropathogenic role of adenylate kinase- 1 in A $\beta$ mediated tau phosphorylation via AMPK and GSK3 $\beta$. Hum Mol Genet 21: 2725-2735.

PEDRÓS I ET AL. 2014. Early alterations in energy metabolism in the hippocampus of APPswe/PS1dE9 mouse model of
Alzheimer's disease. Biochim Biophys Acta 1842: 15561566.

Pietz J, Rupp A, EBInger F, RATING D, MAYATEPEK E, BoESCH C AND KREIS R. 2003. Cerebral energy metabolism in phenylketonuria: findings by quantitative in vivo 31P MR spectroscopy. Pediatr Res 53: 654-662.

RoJAs DB, DE ANDRADE RB, GEMELli T, OLIVEIRA LS, CAMPOS AG, DUTRA-FILHO CS AND WANNMACHER CM. 2012. Effect of histidine administration to female rats during pregnancy and lactation on enzymes activity of phosphoryltransfer network in cerebral cortex and hippocampus of the offspring. Metab Brain Dis 27: 595-603.

TIKHONOVA LA, KAMINSKII YG AND KOSENKO EA. 2014. Effects of amyloid- $\beta$ peptide $A \beta 25-35$ on glycolytic and antioxidant enzymes in erythrocytes of different ages. Biol Bull 41: 312-317.

TOWNSEND KP AND PRATICO D. 2005. Novel therapeutic opportunities for Alzheimer's disease: focus on nonsteroidal anti-inflammatory drugs. FASEB J 19: 1592-1601.

TSUNEKAWA H, NODA Y, MOURI A, YONEDA F AND NABESHIMA T. 2008. Synergistic effects of selegiline and donepezil on cognitive impairment induced by amyloid beta (25-35). Behav Brain Res 190: 224-232.

TZAgOlOFF A. 1982. Mitochondria. New York: Plenum Press 342.

VILLALBA BT, IANISKI FR, WILHELM EA, FERNANDES RS, ALVES MP AND LUCHESE C. 2014. Meloxicam-loaded nanocapsules have antinociceptive and antiedematogenic effects in acute models of nociception. Life Sci 115: 36-43.

VitVitsky VM, GARG SK, KEEP RF, ALBIN RL AND BANERJEE R. 2012. $\mathrm{Na}^{+}$and $\mathrm{K}^{+}$ion imbalances in Alzheimer's disease. Biochim Biophys Acta 1822: 16711681.

Voigt N, Henrich-NoACK P, Kockentiedt S, Hintz W, Tomas J, SABEL BA. 2014. Surfactants, not size or zeta-potential influence blood-brain barrier passage of polymeric nanoparticles. Eur J Pharm Biopharm 87:19-29.

WALLIMANN T, WYSS M, BRDICZKA D, NICOLAY K AND EPPENBERGER HM. 1992. Intracellular compartmentation, structure and function of creatine kinase isoenzymes in tissues with high and fluctuating energy demands: the 'phosphocreatine circuit' for cellular energy homeostasis. Biochem J 281: 21-40.

ZAHID S, OELlERICH M, ASIF AR AND AHMED N. 2014. Differential expression of proteins in brain regions of Alzheimer's disease patients. Neurochem Res 39: 208215 . 